\title{
Learning from others' experience: A taste of parallel corpus analysis for translation students and budding corpus researchers
}

\section{Aprendendo com a experiência dos outros: um gostinho da análise de um corpus paralelo para alunos de tradução e futuros pesquisadores de corpus}

Il libro mio è cresciuto come cresce un bambino: ascoltando e imparando dall'esperienza altrui. Marco Malvaldi, Il borghese Pellegrino, p. 22

Silvia Bernardini*

\footnotetext{
* Professor and Dean of the Department of Interpreting and Translation (DIT) of the University of Bologna, Italy. E-mail: silvia.bernardini@unibo.it

TradTerm, São Paulo, v.37, n. 2, janeiro/2021, p. 370-396

Número Especial - Linguística de Corpus www. revistas.usp.br/tradterm
} 
Abstract: This contribution describes the potential of parallel corpus analysis for the development of research skills in the translation classroom. Using culinary texts as a case in point, and more specifically a culturally salient Italian text from the turn of the 19th century (Pellegrino Artusi's La scienza in cucina e l'arte del mangiar bene/Science in the kitchen and the art of eating well, in its original Italian and translated English version), a detailed analysis is offered of the Italian equivalents of the verb lemma COOK and of the English equivalents of the Italian verb lemma CUOCERE, showing how the paradigmatic and syntagmatic insights thus obtained could be used to construct bilingual lexical/terminological profiles of units of meaning, and/or to shed light on translation strategies and norms, depending on one's research hypotheses and variables. Two more unorthodox uses of parallel corpora to tap into translators' domain-specific knowledge, and as aids in the interpretation of culturally salient historical and literary texts, are also discussed.

Keywords: Culinary texts; Parallel corpora; Translation; Terminology; Pellegrino Artusi.

Resumo: Esta contribuição descreve o potencial da análise de um corpus paralelo para o desenvolvimento de habilidades de pesquisa na sala de aula de tradução. Usando textos culinários como exemplo, e mais especificamente um texto de destaque para a cultura italiana da virada do século 19 (La scienza in cucina e l'arte del mangiar bene / Science in the kitchen and the art of eating well, de Pellegrino Artusi em sua versão original italiana e na tradução para o inglês), realiza-se uma análise detalhada dos equivalentes em italiano do lema verbal COOK e dos equivalentes em inglês do lema verbal italiano CUOCERE, mostrando como os insights paradigmáticos e sintagmáticos resultantes poderiam ser usados para construir perfis lexicais / terminológicos bilíngues de unidades de significado e / ou para lançar luz sobre estratégias e normas de tradução, dependendo das hipóteses e variáveis de cada pesquisa. Também são discutidos dois usos mais heterodoxos de corpora paralelos para explorar o conhecimento dos tradutores acerca de domínios específicos e como auxílio à interpretação de textos históricos e literários marcados culturalmente.

Palavras-chave: Textos culinários; Corpora paralelos; Tradução; Terminologia; Pellegrino Artusi. 


\section{Introduction}

This article focuses on corpora, cooking and translation. As such, it could have been written by Stella Tagnin herself (at least in principle, since she would no doubt have done a better job of it). Indeed, since I'm new to cooking texts as a research topic, I'm rather nervous as I write these words, and imagine Stella reading them. I do hope she is now smiling the warm, encouraging smile she has gifted to scores of students and colleagues throughout the years, and will take this contribution as a token of my love and appreciation for her work.

The argument I'm going to make builds on many years of research on corpus use in the translation classroom, yet the angle is also quite new for me. First, because the study adopts the parallel perspective, rather than the monolingual or bilingual comparable ones; second, because the parallel data consist of the first 252 recipes from Pellegrino Artusi's celebrated cookbook La scienza in cucina e l'arte di mangiar bene /Science in the Kitchen and the art of eating well, in their original Italian (1922, 25th edition) and aligned translated English (2003) versions (henceforth La scienza in cucina/Science in the kitchen). The choice of this very special book will allow me to point out several ways in which parallel corpus data can be used in the education of translators.

The contents of this contribution complement those of another one, in which I lay down what I see as the basic notions that should be covered in an ideal first lesson on corpus linguistics for translators. There I barely touched upon parallel corpora, and I focused more on corpus linguistics than translation. Here the perspective is reversed. I will take for granted the core notions derived from the Neo-Firthian approach to corpus linguistics (that I briefly review and exemplify in 2. below), and reflect instead on how these notions can contribute to the analysis of culturally meaningful parallel texts.

The relevance of parallel data to translation is so obvious as to be of limited pedagogic interest: the success of resources like Linguee or Reverso with translation students, ${ }^{1}$ and the widespread adoption of translation memory software by professionals, suggests that the use of parallel datasets for

\footnotetext{
${ }^{1}$ https://www.linguee.com; https://www.reverso.net/ (visited 31 August 2020)

TradTerm, São Paulo, v.37, n. 2, janeiro/2021, p. 370-396

Número Especial - Linguística de Corpus

www. revistas.usp.br/tradterm
} 
straightforward reference purposes requires less effort, and is more readily grasped by users, than other kinds of corpus resources (ASTON 1999). Yet it would be a mistake to underestimate both the potential and the difficulties involved in interpreting parallel data, particularly when it gets to clarifying one's research hypotheses and corpus design choices and coming up with coherent interpretations.

To focus specifically on this analytical step, in this paper the traditional order of hypothesis making and data analysis is reversed. I will first present the data, and then reflect on their interpretation in the light of different hypotheses. Hopefully readers, in particular learners, will construct their own interpretation of the data, make hypotheses and decide if the data are adequate to support or reject them, before I set out my own interpretations.

Out of the treasure throve of Artusi's translation, I am going to focus on one verb only, the lemma COOK and its main Italian dictionary equivalent CUOCERE. ${ }^{2}$ Inspiration for this choice came from a blog post by Stella entitled "So, what's cooking?", ${ }^{3}$ where she discusses uses of the terms COOK, BOIL and BAKE in the Corpus of Contemporary American English. ${ }^{4}$ Blogging is something Stella has in common with our great gastronome, Pellegrino Artusi: Tuscan author Marco Malvaldi, in his recent crime fiction novel titled Il Borghese Pellegrino (MALVALDI 2020), talks of Artusi himself as the first cooking blogger, for his intense exchange of correspondence with readers and his interactive, engaging writing style. Expertise and knowledge rarely go hand in hand with the ability to teach them to students and popularize them to a lay audience in this way. This is in my view the greatest accomplishment of Stella Tagnin's career: to have done valuable research work, and to have been able to pass it on beyond a restricted circle of experts.

\footnotetext{
${ }^{2}$ Throughout the article lemmas are written in capital letters to distinguish them from word forms.

${ }^{3} \mathrm{http} / / /$ blogdisal.com.br/site/so-whats-cooking-stella-e-o-tagnin/ (visited 31 August 2020)

${ }^{4}$ https://www.english-corpora.org/coca/ (visited 31 August 2020)

TradTerm, São Paulo, v.37, n. 2, janeiro/2021, p. 370-396

Número Especial - Linguística de Corpus

www.revistas.usp.br/tradterm
} 


\section{Background: Translation, corpora, culture, cooking}

\subsection{Translation and (contrastive) corpus linguistics, corpora and translation studies}

Translation data have been used extensively in contrastive corpus linguistics for "the systematic exploitation of the bilingual intuition of translators" (JOHANSSON 2007: 5). According to Johansson (ibid.), translation (or parallel) corpora have the "special advantage" that they make available texts expressing approximately the same meanings and discourse functions in two languages, such that by exploiting them we can build "paradigms of correspondences" (ibid: 9). The procedure consists in selecting a word or phrase in the target (or source) text and collecting its equivalent word(s) or phrase(s) in the source (or target) text. The correspondences can be congruent (the expected translation, sometimes referred to as "dictionary equivalent"), divergent (a more unexpected choice), or null (the word or phrase has no correspondence in the other language). By alternating between the target-tosource and the source-to-target direction, the degree of mutual correspondence, or functional similarity (ALTENBERG 2007) of single expressions and semantic categories can be established without relying on intuition or dictionaries/grammars. We can thus also evaluate the strength of each mutual correspondence (i.e., the likelihood that a given word is translated with another), and its (a)symmetry (i.e., the tendency for one correspondence to be stronger in one translation direction than in the other). Asymmetry would be an effect of translation, or translation bias which, seen from the perspective of contrastive corpus studies, is an unwanted effect, to be controlled for thanks to comparable corpus analysis.

From the perspective of translation studies, however, the focus is reversed: translation effects are the main object of interest, and contrastive differences have to be controlled for. Translation effects can be sought at the

TradTerm, São Paulo, v.37, n. 2, janeiro/2021, p. 370-396

Número Especial - Linguística de Corpus

www. revistas.usp.br/tradterm 
micro-level of single translator's choices (see e.g. hypotheses about translator style, MARCO 2004) or at the slightly more general level of single language pairs/directions (e.g. TEICH 2003 on German <-> English, XIAO AND HU 2015 on English -> Chinese); but they have also been hypothesised to be shared by all translators/languages (as in BAKER's (1993) proposal), or even to all instances of constrained language use (LANSTYÁK \& HeLTAI 2012).

Going into details about this body of work would require too long a digression, but the relevant point here is that corpus methods and resources can be used to shed light on the translation process by focusing on the ways in which text production is affected by it. Simplifying substantially, translation effects can be observed by contrasting translated texts to comparable nontranslated texts in the same language, or by contrasting source and target texts in two languages. Through the former, one can focus on higher-order general textual features (as in, e.g., LAVIOSA 1998), yet relating these features causally to the translation process requires something of an act of faith, since text and corpus comparability across cultures is very difficult to ascertain (BERNARDINI \& ZANETTIN 2004). Contrasting source and target texts in parallel corpora instead shows us the textual effects of tangible decisions made by translators. Generalizability may be an issue, but we get a tangible glimpse (however indirect, as is in the nature of corpus data), of the translation process. As claimed by Aston (1999: online), "[s]ince parallel concordances provide translations of each occurrence, citations are more likely to be immediately understandable for the user, diminishing the difficulties of retrieval and risks of misinterpretation associated with monolingual and comparable corpora".

\subsection{What to look for in texts and corpora: syntagmatic relations and units of meaning}

Being able to efficiently mine information about word use from general and specialised text collections is one of the main competences defining professional translator expertise according to the competence framework of 
the European Master's in Translation Network ${ }^{5}$ and, I would suggest, one of the future skills needed to cope with the twists and turns of a fast-changing profession (EHLERS 2020). Yet it would be wrong to consider corpus linguistics first and foremost as a method for extracting lexical, terminological and phraseological information from text collections. The cognitive effort needed to process corpus data is substantial, and may be off-putting and ultimately unrewarding if one approaches corpora as they would approach reference resources/tools like dictionaries or even translation memories. Coherent with the assumptions of data-driven learning (JoHNS 1991), the main role of corpora in translator education would seem to be as researcher's playgrounds, where learners can come into contact with large amounts of authentic (and therefore messy) textual data, practice their budding research skills on them, and arrive at an understanding of contrastive language use, and of translation as regulated by contextually - and situationally - bound preferences and norms, rather than absolute rules (BERNARDINI ET AL. 2020).

Before we can exemplify this kind of language data exploration, however, we need some basic theoretical notions that we can rely on. A useful distinction, that goes back to Ferdinand de Saussure (1916), concerns paradigmatic and syntagmatic relations. The former, well-known and widely focused upon in linguistics and philosophy, refer to word associations: different verb forms belonging to the same lemma would constitute a verbal paradigm, and different words related to each other by means of different lexical relations (synonymy, antonymy, hyponymy, hypernymy etc.) would constitute a lexical paradigm. Paradigmatic associations are typically part of our language competence (Saussure's langue) because it is unlikely that they appear together in texts (Saussure's parole): normally, we do not need to use two verb forms belonging to the same paradigm together, or two synonyms next to each other (though of course there will be plenty of exceptions to this general principle). Paradigmatic relations are the building blocks of grammar, semantics, logic.

The other relations introduced by Saussure, syntagmatic ones, are less familiar to many of us. This is because they belong to parole, or language

${ }^{5}$ https://ec.europa.eu/info/sites/info/files/emt_competence_fwk_2017_en_web.pdf (visited 31 August 2020)

TradTerm, São Paulo, v.37, n. 2, janeiro/2021, p. 370-396

Número Especial - Linguística de Corpus

www. revistas.usp.br/tradterm 
performance, which, prior to the advent of corpus linguistics, had not generally been the object of linguists' attention. In the words of Sinclair (2004: 10), "linguistics has been formed and shaped on inadequate evidence", namely researchers' or informants' introspection. The Neo-Firthian approach to (corpus) linguistics focuses instead primarily on syntagmatic relations observable in corpus data. It would be wrong to conclude that corpus linguistics is about language performance only, however. If we are able to recognize not only fixed expressions like proverbs and idioms, but also conventionalised word sequences formed according to standard grammar rules, it is because we have encountered them often enough for them to enter our language competence (though not necessarily our language awareness). As claimed by Saussure (1916: 173),

il faut attribuer à la langue, non à la parole, tous les types de syntagmes construits sur des formes régulières. En effet, comme il n'y a rien d'abstrait dans la langue, ces types n'existent que si elle en a enregistré des spécimens suffisamment nombreux.

Syntagmatic relations are more elusive and less intuitively salient than paradigmatic ones, but fortunately they are also more easily observable in corpora - if we know what to look for. According to Sinclair (e.g. 2004: 141 42), frequency data about word co-occurrence obtained from corpora can be categorized at four levels of abstraction. The most basic level is that of collocation, which looks at what words appear together with the word(s) we are studying (we will ignore the methods for ranking collocates, but see e.g. EVERT 2009). In Artusi's Science in the kitchen, the ten most frequent nouns following the verb form cook within four words to the right are water, rice, butter, bain-marie, semolina, broth, flame, peas, milk and meat.

What do we make of this list, from a recipe book? Some nouns probably describe types of foods (rice, semolina, peas, meat), while others are more likely to refer to methods for cooking them (water, butter, bain-marie, broth, flame, milk). We could generalise over these observations by saying that cook has a semantic preference for words belonging to a set that we could label as "foods that are cooked", and another semantic preference for a set that we 
could label "cooking methods". Any other food or cooking method that appeared together with the verb would be added to these sets, regardless of its frequency: even single occurrences thus become relevant, by virtue of their belonging to a semantic set. Notice that semantic preferences are subjective categorizations: the sets are not given, and the grouping may differ from analyst to analyst. For instance, flame and bain-marie might be considered more similar to each other than the rest of the words in this set, and thus worthy of a separate set and label.

Colligation, describing the tendency for a word to co-occur with a set of function words, can be illustrated by the co-occurrence of cook with prepositions. If we go back to the cooking method set, and try to reconstruct their lexico-syntactic structure, we probably end up with cook + [preposition] + water/butter/flame etc. The most frequent grammatical class immediately following cook is indeed that of prepositions (followed by determiners and pronouns). A focused search for cook followed by a preposition would point us to different ways of expressing cooking techniques: cook in (less frequently with) butter or broth, cook on the grill or on a spit, cook over a slow fire or a high flame, and so forth.

The different syntagmatic relations that contribute to the study of units of meaning are not equally relevant for all words. The fourth and most abstract relation, semantic (or evaluative) prosody, is hard to illustrate by way of reference to a simple material process verb like cook. We shall instead use simple as an example. In Science in the Kitchen, the most frequent word following "simple [comma]", and "simple and", is healthy. Other words following these two patterns are nutritious, agreeable, natural, restful, quicker, light, civilized, and appetizing. All these adjectives express a positive evaluation by the author, and this attaches to the (more) neutral simple. Whenever we read of a simple dish, or a simple meal, we do not need other, more explicit, hints: we know that Artusi is appreciative of that dish or meal, because of the positive evaluative prosody of simple. After all, he describes himself as a "simple amateur" (ARTUSI 2003: 7), and conversely derides the "complex flavor" of Budino Gabinetto (Cabinet Pudding) that "tastes of diplomacy" and is mockingly dedicated "to the greatest of ministers, to the cynosure of the hour" who had 
suddenly just plunged into oblivion (ARTUSI 2003: 482-83). Evaluative prosody is more relevant for the study of socio-culturally meaningful texts, while semantic preference is more relevant when approaching scientific or technical texts. $L a$ scienza in cucina belongs to both categories, which is why it is such an interesting object of analysis, as we shall see in 2.3 below.

\subsection{Cooking and culture: why culinary texts, and} Pellegrino Artusi's Science in the kitchen in particular?

Communication in the culinary domain has seen a surge of academic interest in recent years, both within linguistics in general (GERHARDT ET AL. 2013, JURAFSKY 2014) and within translation studies (PARADOWSKI 2018). The sociocultural relevance of the theme hardly needs pointing out, but there are also linguistic and translation-specific issues to consider, that make it especially interesting for translation students. Cookbook translation, for instance, has to convey culturally distinctive practices, ingredients and instruments to a wide audience of readers, from the lay person to the semi-expert, whose level of acquaintance with the culture and/or the techniques may vary considerably. The difficulties faced by technical translators add to the difficulties faced by translators of culturally-laden texts. On the one hand, success conditions for recipes dictate that the reader is able to make a satisfying dish following the instructions provided. On the other, for this success condition to be fulfilled the translator may need to apply a cultural filter, neutralizing or generalizing culture-specific items and ultimately "frustrat[ing] the expectations to taste a foreign flavor" (REBECHI AND TAGNIN 2020: 68), which had probably motivated them to seek out the recipe in the first place. If culinary translation is a challenging area for translation practice, corpora can come to the rescue. Rebechi and Tagnin (2020) offer two main reasons why corpus resources may be especially valuable for culinary translators: first, to address terminological knowledge gaps that may emerge due to the lack of reference materials, and second, to account for differences in the level of technicality of texts in 
different languages, which they observe in their comparison of Anglo-American and Brazilian cookbooks.

The culinary domain thus offers an excellent playground where to practice corpus-based research with translation students. But why focus on a single, rather old and difficult cookbook? First published in 1891, only three decades after Italy became a single country, Pellegrino Artusi's La scienza in cucina is without doubt the best-known Italian cookbook, both nationally and internationally. It was the first Italian cookbook to explicitly address middleclass family cooks and housewives from all over Italy, who in return contributed recipes and comments that were often included in subsequent editions. Mediating, both linguistically and gastronomically, between local traditions and local dialects, Artusi, "the gastronomic father of us all" (BALLERINI 2003), was among the greatest contributors to the development of the Italian nascent national identity (CAPATTI AND MONTANARI 1999: 237-40). This was achieved thanks to a very peculiar, almost dialogic writing style and to the inclusion of anecdotes, stories, digressions and poems alongside the actual cooking instructions. Even though the language is at times difficult for the contemporary reader, the instructions sometimes considered too vague (SCICOLONE 2003), and the recipes somewhat too heavy for current tastes (CAPATTI 2019), the book is still in print, and virtually every household in Italy has a copy. To this day, Italians read La scienza in cucina as testimony of a very significant moment in Italian history and as an utterly enjoyable literary text, as well as a cookbook.

Given the inherent difficulties of translating cooking texts discussed above, the peculiar textual features of Artusi's style, and the author's role as the father of Italian cuisine, parallel analysis of La scienza in cucina and its most highly regarded English translation (BALLERINI 2005) would seem to offer translation students a vantage point from which to appreciate the complexity of an endeavour straddling the traditional opposition between literary and technical translation (WITTMAN 2012, OLOHAN 2012). 


\section{Method}

Data collection for this case study of the verb lemma COOK consisted in first obtaining the Italian and English electronic versions of Artusi's book. While several editions of the original Italian exist, as well as several English translations, there were two obvious candidates on which the choice fell. On the one hand, for Italian, the version published by the Project Gutenberg Literary Archive Foundation was used. ${ }^{6}$ This is a high-quality plain text version of the 25th edition, published in 1922. As for the English version, since no plain text version was readily available, the text was copied from the PDF version of Science in the Kitchen, published in 2003 by the University of Toronto Press. While this is not the only English version available, it is the most recent and readily available, and the translation, by Murtha Baca and Stephen Sartarelli, is considered "excellent" by the editor and leading North-American Artusi expert, Luigi Ballerini (2005). Differently from the Italian text, the English one had to undergo bulk changes using regular expressions to correct obvious conversion problems, following a cursory reading and random manual checks. Despite these efforts, the quality of the English text remains lower than that of the Italian one.

Both texts were uploaded to the SketchEngine ${ }^{7}$ as separate corpora. For the parallel version, the two text were then stripped of front and back matter, leaving only the 790 recipes. Alignment was performed using the freely available InterText editor sof tware, ${ }^{8}$ that allows one to cyclically align, correct and realign the texts before exporting them as Translation Memory Exchange (TMX) format, one of the formats that allow direct upload to the SketchEngine. InterText editor also makes it possible to correct minor errors in the texts, which turns out to be very useful when dealing with automatically converted text (as was the case with the English text). In the interest of time, only about one third of the text was aligned, namely the first 252 recipes: based on a

\footnotetext{
${ }^{6} \mathrm{http} / / /$ www.gutenberg.org/ebooks/59047

${ }^{7}$ https://www.sketchengine.eu (visited 31 August 2020)

${ }^{8} \mathrm{https}$ ://wanthalf.saga.cz/intertext (visited 31 August 2020)

TradTerm, São Paulo, v.37, n. 2, janeiro/2021, p. 370-396

Número Especial - Linguística de Corpus

www. revistas.usp.br/tradterm
} 
monolingual search of the whole text, which had yielded 481 occurrences of COOK, this sample of about 170 pages was judged to be large enough to provide a sizeable number of occurrences (around 100), representative of the whole. The 11 sections (out of 23) included in the sample are Broths, Aspic, and Sauces; Soups and Pastas with Broth; Pasta Dishes and Soups in Vegetable Stock; Appetizers; Sauces; Eggs; Doughs and Batters; Stuffings; Fried Foods; Boiled Meats; Entremets.

A query for the verb lemma COOK in the English subcorpus was submitted, and parallel concordance lines downloaded as a MS Excel spreadsheet. Based on a parallel analysis, the most frequent (or "default") Italian equivalent lemma was then searched for in the Italian subcorpus (CUOCERE), and parallel concordance lines were downloaded. This two-way comparison allows us to observe cross-linguistic correspondences and translation strategies from the point of view of the target and the source languages, as discussed in section 4 . below.

\section{Results}

\subsection{Target-to-source correspondences}

As shown in table 1., the default equivalent CUOCERE, together with the noun COTTURA, take up $72 \%$ of all the source occurrences. The percentage is worth bearing in mind, but these cases will not be further studied, as they correspond to our expectations - they will feed back into the analysis later on, as we reverse the perspective and look for English equivalents of CUOCERE in the target text. We shall also ignore the three cases $(2 \%)$ in which COOK corresponds to Italian CUCINARE (a synonym of CUOCERE), and focus instead on the more surprising choices. 
Table 1 - target-to-source correspondences of COOK. ${ }^{9}$

\begin{tabular}{|l|l|l|}
\hline & Frequency & Percentage \\
\hline CUOCERE + COTTURA [Noun] & 108 & $72 \%$ \\
\hline $\begin{array}{l}\text { TIRARE, TIRARE a cottura, TIRARE a } \\
\text { sapore }\end{array}$ & 13 & $8.6 \%$ \\
\hline no source text equivalent & 8 & $5.3 \%$ \\
\hline $\begin{array}{l}\text { BOLLIRE + BOLLITURA [Noun] } \\
\text { (BOIL/SIMMER) }\end{array}$ & 5 & $3.3 \%$ \\
\hline CUCINARE & 3 & $2 \%$ \\
\hline LESSARE (BOIL/SIMMER) & 2 & $1.3 \%$ \\
\hline RESTRINGERE (COOK down) & 2 & $1.3 \%$ \\
\hline SERVIRSI (USE) & 1 & $0.6 \%$ \\
\hline OCCORRE (NEED) & 1 & $0.6 \%$ \\
\hline BAGNARE (MOISTEN) & 1 & $0.6 \%$ \\
\hline RITIRARE (DRY) & 1 & $0.6 \%$ \\
\hline STRUGGERE (DISSOLVE) & 1 & $0.6 \%$ \\
\hline BASTARE (BE enough) & 1 & $0.6 \%$ \\
\hline PREPARARE (PREPARE) & 1 & $0.6 \%$ \\
\hline SOFFRIGGERE (FRY) & 1 & $0.6 \%$ \\
\hline METTERE in forma (PUT in a mold) & 1 & $0.6 \%$ \\
\hline Total & 150 & $100 \%$ \\
\hline
\end{tabular}

There are 13 occurrences of COOK (8.6\% of the total) that translate the Italian term TIRARE, with its variants TIRARE a cottura and TIRARE a sapore (a rather unusual phrase in current Italian). The term describes a process whereby something is cooked by adding liquid to it from time to time, letting it dry, and then adding more. The verb focuses on the end result: if the instruction is to tirare a cottura, then the resulting state is that of food that is a) done, and b) in a dry-ish state (as in a risotto, the typical dish that is cooked in this way). The English text sometimes emphasises the end point of the process (cook thoroughly, finish cooking, simmer until cooked), but typically leaves the dryish state out, as in examples 1-3 below:

\footnotetext{
${ }^{9}$ Glosses are provided only where congruent decontextualised equivalents (other than COOK) exist.

TradTerm, São Paulo, v.37, n. 2, janeiro/2021, p. 370-396

Número Especial - Linguística de Corpus www. revistas.usp.br/tradterm
} 


\begin{tabular}{|l|l|l|}
\hline 1 & $\begin{array}{l}\text { The meat stuffing, consisting of } \\
\text { chickpea-size chunks, is best made with } \\
\text { chicken livers, white chicken meat, } \\
\text { sweetbreads and the like, and then } \\
\text { cooked in brown stock and bound with } \\
\text { a pinch of flour. }\end{array}$ & $\begin{array}{l}\text { Il battuto di carne, a pezzetti grossi } \\
\text { quanto i ceci, sarà bene farlo con } \\
\text { fegatini, petti di pollo, animelle e cose } \\
\text { simili tirate col sugo di carne e legate } \\
\text { con una presa di farina; }\end{array}$ \\
\hline 2 & $\begin{array}{l}\text { All manner of vegetables, simply boiled } \\
\text { or cooked in butter, may be used in } \\
\text { omelettes, and one may add as well a } \\
\text { pinch of grated Parmesan cheese, by } \\
\text { itself or with parsley. }\end{array}$ & $\begin{array}{l}\text { Ogni erbaggio o semplicemente lessato } \\
\text { o tirato a sapore col burro, serve per le } \\
\text { frittate, come può servire un pizzico di } \\
\text { parmigiano solo o mescolato con } \\
\text { prezzemolo. }\end{array}$ \\
\hline 3 & $\begin{array}{l}\text { No chard, no ink, and when the } \\
\text { cuttlefish, as I have described above, } \\
\text { start to turn yellow, add the rice and } \\
\text { cook thoroughly in hot water and } \\
\text { tomato sauce (recipe 6) or tomato } \\
\text { paste, adding some butter for more } \\
\text { flavor and a better appearance. }\end{array}$ & $\begin{array}{l}\text { Niente bietola, niente inchiostro, e } \\
\text { quando le seppie, come si è detto, } \\
\text { cominciano a prendere il giallo, versate } \\
\text { il riso e tiratelo a cottura con acqua } \\
\text { calda e sugo di pomodoro o conserva, } \\
\text { dandogli più grazia e sapore con un } \\
\text { pezzetto di burro; }\end{array}$ \\
\hline
\end{tabular}

The next category down, with eight occurrences $(5.3 \%$ of the total), is that of additions: the Italian source sentence contains no obvious term corresponding to COOK in translation. The translators have added information that remains implicit in the source, making the instructions clearer, as in examples 4-6.

\begin{tabular}{|l|l|l|}
\hline 4 & $\begin{array}{l}\text { If you have no brown stock, sauté a } \\
\text { little onion in olive oil and butter, } \\
\text { adding salt, pepper and the usual } \\
\text { spices, and then use the mixture to } \\
\text { cook the spleen. }\end{array}$ & $\begin{array}{l}\text { In mancanza di questo, servitevi di un } \\
\text { battutino di poca cipolla, olio, burro, } \\
\text { sale, pepe e spezie per condimento. } \\
\text { [for seasoning] }\end{array}$ \\
\hline 5 & $\begin{array}{l}\text { When this is done, immediately pour } \\
\text { the broth over the drained, partly } \\
\text { cooked macaroni. I\# I I say }\end{array}$ & $\begin{array}{l}\text { ciò ottenuto, versatelo subito sui } \\
\text { maccheroni già sgrondati dall'acqua e } \\
\text { immediately, because otherwise the } \\
\text { dico_subito_, perchè altrimenti il } \\
\text { gruiera cala a fondo e si appasta. [on } \\
\text { the drained macaroni] }\end{array}$ \\
\hline 6 & $\begin{array}{l}\text { Keep the tagliatelle al dente, and salt } \\
\text { the water you are cooking them in very } \\
\text { sparingly given that the sauce has }\end{array}$ & $\begin{array}{l}\text { Le tagliatelle cuocetele poco e salatele } \\
\text { pochissimo a motivo del prosciutto: } \\
\text { levatele asciutte, conditele col detto } \\
\text { intingolo e con parmigiano. [salt them } \\
\text { prosciutto in it. Strain the pasta and } \\
\text { dress it with the sauce and Parmesan } \\
\text { cheese. }\end{array}$ \\
\hline
\end{tabular}

In example 6, for instance, the instruction is to salt the tagliatelle. While

TradTerm, São Paulo, v.37, n. 2, janeiro/2021, p. 370-396

Número Especial - Linguística de Corpus www. revistas.usp.br/tradterm 
comprehensible, this is technically imprecise, since tagliatelle are boiled in water, and one does not salt them, but the water they are cooked in.

Further down the list we find five occurrences $(3.3 \%)$ of $C O O K$ translating BOLLIRE and two of LESSARE (1.3\%), both of which would approximately correspond to the English verbs BOIL/SIMMER. The use of BOLLIRE in some of these cases would indeed be rather unusual in modern Italian as well, since the cooking method is more akin to stewing than boiling/simmering (as in 7). In other cases, like 8, the verb co-occurs with the noun brodo (broth), and as such would seem to correspond to prototypical cases of the boiling cooking method.

\begin{tabular}{|l|l|l|}
\hline 7 & $\begin{array}{l}\text { Cover the pan with a plate, on which you } \\
\text { will place a little water, and cook the } \\
\text { meat at a gentle simmer for six hours. }\end{array}$ & $\begin{array}{l}\text { Coprite il tegame con un piatto che lo } \\
\text { chiuda e sul quale sia mantenuta } \\
\text { sempre dell'acqua e fate bollire la } \\
\text { carne per sei ore continue, ma in modo } \\
\text { che il bollore appena apparisca. [make } \\
\text { the meat boil] }\end{array}$ \\
\hline 8 & $\begin{array}{l}\text { Cut the mixture into little bricks or cakes } \\
\text { as thick as a heavy coin and between 1 } \\
\text { or } 2 \text { centimeters wide (about } 1 / 2 \text { inch), } \\
\text { which you will cook in broth for a few } \\
\text { minutes. }\end{array}$ & $\begin{array}{l}\text { Tagliatelo a mattoncini o a mostaccioli } \\
\text { della grossezza di uno scudo e della } \\
\text { larghezza di un centimetro o due e } \\
\text { gettateli nel brodo facendoli bollire } \\
\text { qualche minuto. [drop them in the } \\
\text { broth and boil them] }\end{array}$ \\
\hline
\end{tabular}

The tail of the list consists of nine verbal processes, each occurring once only $(0.6 \%$, the singletons taken together accounting for $6 \%$ of the total). All but one of the verbs (9-17), with their immediate co-texts, depict the action to be performed more precisely than the source expressions they translate. The one exception is number 18 , where COOK translates the arguably more precise SOFFRIGGERE (meaning brown, sauté). The translators may have opted for the more generic COOK because soffriggere in this co-text would be unusual also in Italian today (in itTenTen16 it has among its objects ingredients like onion, garlic, bacon etc., rather than sliced meat). Or they may have made this choice not to repeat BROWN or SAUTÉ, both verbs having been used (of lard and onion respectively) in the preceding sentences. 


\begin{tabular}{|c|c|c|}
\hline 9 & $\begin{array}{l}\text { During the hunting season, a skillful chef } \\
\text { may cook it in a mold, stuffing it with } \\
\text { stewed birds. }\end{array}$ & $\begin{array}{l}\text { Nel tempo della cacciagione un abile } \\
\text { cuoco può metterla in forma } \\
\text { riempiendola di uccelletti cotti in umido. } \\
\text { [can place it in a mold] }\end{array}$ \\
\hline 10 & $\begin{array}{l}\text { There are many people who, ignorant of } \\
\text { the ways of food preparation, have a } \\
\text { horror of garlic merely because they can } \\
\text { smell it on the breath of those who have } \\
\text { eaten it raw or poorly cooked. }\end{array}$ & $\begin{array}{l}\text { Ci sono molte persone, le quali, ignare } \\
\text { della preparazione dei cibi, hanno in } \\
\text { orrore l'aglio per la sola ragione che lo } \\
\text { sentono puzzare nel fiato di chi lo ha } \\
\text { mangiato crudo o mal preparato; } \\
\text { [unskilfully prepared] }\end{array}$ \\
\hline 11 & $\begin{array}{l}\text { Turn them often and when they are all } \\
\text { red, baste them with tomato sauce } \\
\text { (recipe 6) or tomato paste. Then add } \\
\text { enough hot water to cook the rice. }\end{array}$ & $\begin{array}{l}\text { Rivoltateli spesso e quando tutti saranno } \\
\text { divenuti rossi, bagnateli con sugo di } \\
\text { pomodoro o conserva e poco dopo } \\
\text { versate tanta acqua calda che possa } \\
\text { bastare pel riso. [that can be enough for } \\
\text { the rice] }\end{array}$ \\
\hline 12 & $\begin{array}{l}\text { For cooking instructions, follow recipe } \\
75, \text { keeping in mind that this risotto will } \\
\text { be more substantial and flavorful if } \\
\text { cooked in broth. }\end{array}$ & $\begin{array}{l}\text { Per la cottura regolatevi come al N. } 75 . \\
\text { Per rendere questo risotto più } \\
\text { sostanzioso e più grato al gusto occorre il } \\
\text { brodo. [broth is needed] }\end{array}$ \\
\hline 13 & $\begin{array}{l}\text { You may cook this dish in water instead } \\
\text { of broth, and serve it quite dry. }\end{array}$ & $\begin{array}{l}\text { Invece di brodo potete servirvi di acqua e } \\
\text { farlo asciutto: [avail yourselves of water] }\end{array}$ \\
\hline 14 & $\begin{array}{l}\text { Chop the vegetables well and begin by } \\
\text { sautéing the onion in oil. When the } \\
\text { onion turns a golden brown, add the } \\
\text { other vegetables. Season with salt and } \\
\text { pepper, stirring constantly. Let the } \\
\text { vegetables cook until they have } \\
\text { reabsorbed their own water. }\end{array}$ & $\begin{array}{l}\text { Tritate alquanto gli erbaggi e mettete per } \\
\text { prima la cipolla a soffriggere nell'olio e } \\
\text { quando questa avrà preso colore gettate } \\
\text { giù gli altri, conditeli con sale e pepe, } \\
\text { rimestate spesso e lasciate che ritirino } \\
\text { l'acqua che fanno. [let them reabsorb the } \\
\text { water they let out] }\end{array}$ \\
\hline 15 & $\begin{array}{l}\text { Cut the meat into little cubes and mince } \\
\text { the bacon and the herbs finely with a } \\
\text { mezzaluna. Put all the main ingredients } \\
\text { on the fire with the butter. When the } \\
\text { meat has browned, add the pinch of } \\
\text { flour and then cook in broth until done. }\end{array}$ & $\begin{array}{l}\text { Tagliate la carne a piccoli dadi, tritate } \\
\text { fine colla lunetta la carnesecca, la cipolla } \\
\text { e gli odori, poi mettete al fuoco ogni cosa } \\
\text { insieme, compreso il burro, e quando la } \\
\text { carne avrà preso colore aggiungete il } \\
\text { pizzico della farina, bagnando col brodo } \\
\text { fino a cottura intera. [ } \underline{\text { moistening with }} \\
\text { broth] }\end{array}$ \\
\hline 16 & $\begin{array}{l}\text { Take a domestic duck, put it into a } \\
\text { saucepan with some butter, season with } \\
\text { salt and pepper, and when it begins to } \\
\text { brown, add a battuto made with } \\
\text { prosciutto, onion, celery and carrot, } \\
\text { which you will place under the bird to } \\
\text { cook. Remember to turn the duck } \\
\text { regularly. }\end{array}$ & $\begin{array}{l}\text { Prendete un'anatra domestica, mettetela } \\
\text { in cazzaruola con un pezzetto di burro, } \\
\text { conditela con sale e pepe e, quando avrà } \\
\text { preso colore, aggiungete un battuto, } \\
\text { tritato ben fine, di prosciutto, cipolla, } \\
\text { sedano e carota. Lasciatelo struggere } \\
\text { sotto l'anatra, rivoltandola spesso; } \\
\text { [dissolve] }\end{array}$ \\
\hline
\end{tabular}




\begin{tabular}{|l|l|l|}
\hline 17 & $\begin{array}{l}\text { During the hunting season, a skillful chef } \\
\text { may cook it in a mold, stuffing it with } \\
\text { stewed birds. }\end{array}$ & $\begin{array}{l}\text { Nel tempo della cacciagione un abile } \\
\text { cuoco può metterla in forma } \\
\text { riempiendola di uccelletti cotti in umido. } \\
\text { [place it in a mold] }\end{array}$ \\
\hline 18 & $\begin{array}{l}\text { Once dry, add lard and sauté. When the } \\
\text { onion begins to brown, add the liver, } \\
\text { which should be cut into thin slices. } \\
\text { Let it cook for a while, along with the } \\
\text { onion. }\end{array}$ & $\begin{array}{l}\text { asciutta che sia versateci il lardo per } \\
\text { friggerla, e quando avrà preso il color } \\
\text { marrone uniteci il fegato tagliato a fette } \\
\text { sottili. Lasciatelo soffriggere alquanto, } \\
\text { frammisto alla cipolla; [brown/sauté] }\end{array}$ \\
\hline
\end{tabular}

\subsection{Source-to-target correspondences: CUOCERE}

Having analyzed the source text correspondences of $\mathrm{COOK}$, the next step in the analysis consists in reversing the perspective and looking at target text correspondences of the lemma CUOCERE. It will be remembered from 4.1 that this verb lemma accounts for the sheer majority of source text correspondences of $\operatorname{coOK}$ ( $68 \%$ of the total).

Table 2. source-to-target correspondences of CUOCERE

\begin{tabular}{|l|l|l|}
\hline & Frequency & Percentage \\
\hline COOK & 85 & $64.8 \%$ \\
\hline done & 22 & $16.8 \%$ \\
\hline BOIL & 6 & $3.8 \%$ \\
\hline BOIL (CUOCERE $(a)$ lesso) & 3 & $2.3 \%$ \\
\hline BAKE & 2 & $1.5 \%$ \\
\hline no equivalent & 2 & $1.5 \%$ \\
\hline ready & 1 & $0.8 \%$ \\
\hline STEW & 1 & $0.8 \%$ \\
\hline STEW in the oven & 1 & $0.8 \%$ \\
\hline TURN soft and translucent & 1 & $0.8 \%$ \\
\hline FRY [...] with some butter & 1 & $0.8 \%$ \\
\hline ROAST & 1 & $0.8 \%$ \\
\hline GRILL & 1 & $0.8 \%$ \\
\hline SAUTÉ & 1 & $0.8 \%$ \\
\hline PLACE & 1 & $0.8 \%$ \\
\hline ADD & 1 & $0.8 \%$ \\
\hline PREPARE & 1 & $0.8 \%$ \\
\hline Total & 131 & $100 \%$ \\
\hline
\end{tabular}


The results in table 2 . show, unsurprisingly, that in the majority of cases (85 out of 131 , or $64.8 \%$ of the total) CUOCERE is translated as COOK. In some of these cases, the action is not further specified (example 19). This happens especially when the past participle cotto appears in the source text, indicating a completed action or end state. In most other cases CUOCERE is further specified by way of reference to an ingredient or cooking technique (examples 20-22). In these cases, more specific verbs could have been used instead of the generic COOK (brown or sauté for cook in butter, boil or simmer for cook in water/broth), yet the target text is unambiguous thanks to the specification. In a similar case PREPARE is used instead of COOK, but once again the sense is clear thanks to the specification (cotte nell'acqua salata > prepare [...] in salted water).

\begin{tabular}{|l|l|l|}
\hline 19 & $\begin{array}{l}\text { Keep the dough on the fire until the flour } \\
\text { is thoroughly cooked (10 minutes), } \\
\text { stirring constantly. }\end{array}$ & $\begin{array}{l}\text { Tenete la pasta sul fuoco fino a che la } \\
\text { farina sia ben cotta (10 minuti) } \\
\text { rimovendola sempre; }\end{array}$ \\
\hline 20 & $\begin{array}{l}\text { Cuocete i fegatini nel burro e quando } \\
\text { I'avranno tirato bagnateli con brodo; }\end{array}$ & $\begin{array}{l}\text { Cook the livers in butter, and when they } \\
\text { have absorbed it cover with broth. }\end{array}$ \\
\hline 21 & $\begin{array}{l}\text { Per non consumar tanto brodo } \\
\text { imbiancate_il riso nell'acqua e } \\
\text { terminate di cuocerlo col brodo dei detti } \\
\text { polli. }\end{array}$ & $\begin{array}{l}\text { To avoid using too much broth, first } \\
\text { blanch the rice in water, and then finish } \\
\text { cooking it in the broth made by the } \\
\text { chicken }\end{array}$ \\
\hline 22 & $\begin{array}{l}\text { Condite con questo intingolo gli } \\
\text { spaghetti cotti in acqua poco salata, } \\
\text { procurando che restino durettini. }\end{array}$ & $\begin{array}{l}\text { Use this sauce to dress the spaghetti } \\
\text { cooked in lightly salted water, making sure } \\
\text { they turn out al dente. }\end{array}$ \\
\hline
\end{tabular}

In several other cases in which the past participle cotto appears in the source text, indicating a completed action or end state, the target text has done (22 occurrences, $16.8 \%$ of the total) or ready (1 occurrence), and in two cases the term is removed altogether, possibly because the end state can easily be inferred from the preceding instructions.

To the exclusion of two cases in which place and add translate mettere a cuocere (literally put to cooking), all remaining instances have more specific verbs than COOK, sometimes accompanied by specifications. These are worth considering in greater detail, to discern the reason for the greater specificity. We can observe two cases: one in which the target text expression does specify the technique further, and another in which the target text expression TradTerm, São Paulo, v.37, n. 2, janeiro/2021, p. 370-396 
translates a unit of meaning with CUOCERE at its core.

In the first set we find six occurrences of BOIL, three of $B A K E$, and single occurrences of four other verbal expressions. As illustrated by example 23, boil in the broth translates cotta nel brodo. This is very similar to 21 (above), where COOK in broth translates CUOCERE col brodo. In both cases the specification (nel/col brodo > in the broth) is present in the source text as well, yet in 23 the cooking technique is also encoded through the verb BOIL. Similarly, in example 24, cotte in forno (cooked in the oven) is translated as stewed in the oven and in 25 cotte in forma (mold cooked) is translated as mold-baked. In examples 26-28 the cooking technique remains implicit in the source, where it could only be inferred by reading the recipe as a whole and/or calling on cooking knowledge: the tartlet is cooked by baking it, the teal duck is cooked by sautéing it, and the mix is cooked by frying it. Finally, example 28 adds information that could not be inferred from the co-text but only from previous knowledge: the source text author assumes that the end state corresponding to cooked is known to the readers, while the translators describe it: the onion is cooked when it turns soft and translucent.

\begin{tabular}{|c|c|c|}
\hline 23 & $\begin{array}{l}\text { Cotta la pasta nel detto brodo } \\
\text { scolatela bene e conditela a suoli con } \\
\text { questa carne tritata, burro e } \\
\text { parmigiano a buona misura. }\end{array}$ & $\begin{array}{l}\text { Boil the pasta in the broth, then drain and } \\
\text { season with the minced teal meat, butter and } \\
\text { a good measure of Parmesan cheese, making } \\
\text { a few layers. }\end{array}$ \\
\hline 24 & $\begin{array}{l}\text { Le_cottarone_, per chi non lo sa, } \\
\text { sono mele o pere, per lo più } \\
\text { cascaticce, cotte in forno entro una } \\
\text { pentola nella quale si versa un } \\
\text { gocciolo d'acqua, coprendone la } \\
\text { bocca con un cencio bagnato. }\end{array}$ & $\begin{array}{l}\text { "Cottarone," for those who do not know } \\
\text { them, are apples and pears, mostly overripe, } \\
\text { that are stewed in the oven in a small pan } \\
\text { with a little water in it, while the top of the } \\
\text { pan is covered with a moist kitchen towel. }\end{array}$ \\
\hline 25 & $\begin{array}{l}\text { Il pasticcino cuocendo rigonfia } \\
\text { naturalmente e lascia un vuoto } \\
\text { nell'interno; }\end{array}$ & $\begin{array}{l}\text { As the tartlet is baking, it will naturally puff } \\
\text { up with air, remaining rather hollow inside. }\end{array}$ \\
\hline 26 & $\begin{array}{l}\text { Prendete un'arzavola e, vuotata e } \\
\text { pulita come le suddette, mettetela a } \\
\text { cuocere insieme con un battuto di } \\
\text { cipolla (un quarto o mezza se è } \\
\text { piccola), un bel pezzo di sedano, } \\
\text { mezza carota, grammi } 40 \text { di prosciutto } \\
\text { grasso e magro e un pezzetto di } \\
\text { burro; sale e pepe per condimento. }\end{array}$ & $\begin{array}{l}\text { Take one teal, clean it as described in the } \\
\text { preceding recipe, and sauté it in a battuto } \\
\text { made with a quarter of an onion (half if the } \\
\text { onion is small), a good-sized stalk of celery, } \\
\text { half a carrot, } 40 \text { grams (about } 1-1 / 3 \text { ounces) } \\
\text { of untrimmed prosciutto, and some butter, } \\
\text { seasoning with salt and pepper. }\end{array}$ \\
\hline
\end{tabular}

TradTerm, São Paulo, v.37, n. 2, janeiro/2021, p. 370-396

Número Especial - Linguística de Corpus www. revistas.usp.br/tradterm 


\begin{tabular}{|c|c|c|}
\hline 27 & $\begin{array}{l}\text { Gettate questo intriso in padella per } \\
\text { cuocerlo in bianco con burro, olio o } \\
\text { lardo e quando è assodato da una } \\
\text { parte voltatelo con un piatto } \\
\text { dall'altra, ed eccovi il tondone. }\end{array}$ & $\begin{array}{l}\text { Put this mix into a skillet and fry it only with } \\
\text { some butter, olive oil or lard. When it has } \\
\text { firmed up on the bottom, use a dish to flip it } \\
\text { over on the other side. Now you have a } \\
\text { tondone. }\end{array}$ \\
\hline 28 & Quando è cotta mettetela da parte. & $\begin{array}{l}\text { When the onion has turned soft and } \\
\text { translucent, remove it from the pan and put } \\
\text { to one side. }\end{array}$ \\
\hline
\end{tabular}

The six occurrences in the second set illustrate the case where the target text has a single verb that translates a unit of meaning with CUOCERE at its core. In Italian the cooking technique is encoded in the prepositional phrase that follows the verb, rather than the verb supporting it (not so in English): BOIL (CUOCERE a lesso, 3 occurrences), STEW (CUOCERE in umido, 1), ROAST (CUOCERE arrosto, 1) and GRILL (CUOCERE in gratella, 1).

\subsection{Summing up}

At this point we can try and distill a few overall tendencies out of the chaos of authentic text, ignoring the inevitable exceptions. For the time being we will refrain from interpreting these tendencies, and leave this final step for section 5. below. The analysis of source equivalents of COOK when this verb does not translate its obvious Italian equivalents (CUOCERE and CUCINARE) points to two main tendencies: on the one hand, COOK translates more specific terms, generalizing over cooking techniques that might be unusual or difficult to understand for current source text readers as well. On the other, COOK is added or used in place of more general, vague verbs, making the instruction more easily interpretable.

The analysis of target equivalents of CUOCERE confirms that COOK is the obvious choice. We observed several cases in which CUOCERE is in fact the core of a longer unit of meaning, formed of the verb plus a preposition phrase that specifies it (e.g. CUOCERE nel brodo). These are translated by means of a corresponding expression (e.g. COOK in the broth), by a more specific verb that encapsulates the entire unit of meaning (e.g. BOIL), or by the more specific verb and a specifying prepositional phrase (e.g. BOIL in the broth). Finally, several instances of specification were also observed in the target text, 
whereby information that readers of the source text can only infer from the cotext, or from their disciplinary knowledge, is made explicit.

\section{Discussion}

How do we interpret the findings presented in the previous section and make them relevant for translator education? First, in line with Johansson's (2007) and Altenberg's (2007) suggestions, they can be used in the translation classroom to practice constructing bilingual lexical and terminological profiles. Our data are incomplete since, due to space limitations, we only focused on the divergent solutions. Even so, the two-way comparison (from target to source and from source to target) highlighted non-obvious bilingual correspondences (e.g., the frequent translation of the past participle cotto as done or ready) and pointed to the existence of units of meaning that are encoded syntagmatically in one language and as single verb forms in the other (cook down/restringere; cuocere a lesso/boil). Through the mediation of parallel corpus data, Saussure's syntagmatic and paradigmatic relationships are brought together in a single account. COOK, with its collocates, colligates and semantic preferences constitutes a unit of meaning at the monolingual, syntagmatic level. The source and target equivalents of this unit of meaning highlight paradigmatic relations of synonymy, hyponymy, specification etc. in Italian, encoded both as single words (both nouns and verbs) and as syntagms. The same process can be applied to CUOCERE and its English equivalents, and from English equivalents back to Italian correspondences, leading to the bilingual mapping of concept networks (in this case cooking methods).

Contrastive linguists have pointed to the risks of translation bias, and translation studies scholars have turned this bias into their primary research interest, as discussed in 2.1 above. Therefore, adopting the translation scholar viewpoint, one could interpret these findings in the light of the translators' hypothesised decision-making process, relating it to the strategy (NORD 1991) or initial norm (TOURY 1995) they seem to follow. We observed three types of decisions that may appear to partly conflict with each other. Information available from the co-text, or disciplinary knowledge assumed to be shared, is made explicit; the verb COOK is added or used in place of more general, vague 
verbs; cooking terms that might be unusual or difficult also for Italian readers today are generalized. While seemingly divergent, explicitation/specification and generalization processes thus contribute to making recipe instructions in Science in the Kitchen more readable and understandable.

These observations could be interpreted as confirming research findings on typical features of translation (particularly as concerns the explicitation hypothesis, BLUM-KULKA 1986). Or they could be used to pursue research on the translators' strategies and translation norms, taking advantage of the peculiar nature of the source text. In the light of its historical and literary import, translating La Scienza in Cucina would arguably require a source-oriented, documentary approach. Yet in the light of its instructional function as a cookbook, an instrumental, target-oriented approach might be appropriate. While no firm conclusions can be drawn, since the very choice of verb has led to a focus on the instructional function, the analysed data would suggest that an instrumental approach is favoured by the translators. This would also be in line with the operation of a more general initial norm favouring acceptability over adequacy (TouRY 1995: 79).

I would like to conclude this section by drawing attention to the role of translators as text interpreters and of translation as interpretive language use (GUTT 1991). In this article, as in corpus linguistics and corpus-based translation studies, the assumption is that translation data display distinctive features that make it different from, and unrepresentative of, non-translated language use. While checks of translated data against non-translated data sources are often necessary, depending on the purposes of one's study, we should refrain from considering translated data as somewhat defective, or inferior to nontranslated data. Translation data from parallel corpora in fact give access to textually encoded expert knowledge that is especially valuable, and hard to come by. Sociocognitive terminological research infers subject specialist knowledge from the analysis of defining texts written by experts, on the assumption that concepts do not "exist as independent units in the objective world, as traditional Terminology would have us believe. What do exist are texts in which authors give testimony of how they understand categories" (TEMMERMAN 2000: 90). Through their interpretations of source texts, that parallel corpora 
make systematically accessible, I would suggest that translators, as communication and domain experts, give a similar testimony. Finally, and somewhat unorthodoxically, I would also encourage contemporary Italian readers of La scienza in cucina who can read English to take advantage of the modern, reader-friendly interpretation of Artusi's classic offered by Science in the Kitchen, using it as a gloss. An anecdotal example may suffice: my native speaker intuition, supported by dictionary evidence, ${ }^{10}$ tells me that the rather old-fashioned adjective/adverb alquanto describes a largish quantity, closer to a lot than to a little. Yet this interpretation would lead to catastrophic mistakes when trying out Artusi's recipes since, as is clear from the parallel concordances, the word is in fact used to mean fairly, a little, somewhat, rather.

\section{Conclusion}

In this contribution I have attempted to illustrate some of the insights one can gain from parallel corpus data, relying on a substantial extract from Pellegrino Artusi's La scienza in cucina and its English translation Science in the Kitchen as data sources. The results of the parallel analysis of the verb COOK and of its main Italian equivalent CUOCERE have been presented and used to illustrate four uses of parallel corpus data: to set-up of bilingual terminological profiles combining paradigmatic and syntagmatic relations, to explore translation strategies and norms, to tap into the expert knowledge of translators as domain experts, and to aid in the reading of old or complex texts.

Clearly, none of these aims could be achieved without reference to other data sources, such as comparable translated and non-translated texts in the source and target languages, representing the work of a wider range of authors and translators. Setting up a proper study along these lines would require a clear identification of research questions and the sourcing of adequate datasets to tease apart the corresponding variables. In the same way as corpus use in the translation classroom can help translation students to make less "innocent", more informed translation choices (TAGNIN 2002), it is hoped that, by engaging

\footnotetext{
${ }^{10}$ https://dizionari.corriere.it/dizionario_italiano/A/alquanto.shtml (visited 31 August 2020)

TradTerm, São Paulo, v.37, n. 2, janeiro/2021, p. 370-396

Número Especial - Linguística de Corpus

www. revistas.usp.br/tradterm
} 
with the results of corpus analysis along the lines laid out in this toy study, students of translation will also become less innocent learners-as-researchers (Gavioli 2001).

\section{References}

ALTENBERG, B. The correspondence of resultive connectors in English and Swedish, 2007. NJES: Nordic Journal of English Studies, vol. 6, n.1, pp. $1-26$.

ARTUSI, P. La scienza in cucina e l'arte di mangiar bene. 25th edition. Firenze: Bemporad, 1922 [1861]. Project Guthenberg electronic edition: http://www.gutenberg.org/ebooks/59047 (visited: 24 August 2020)

ARTUSI, P. Science in the kitchen and the art of eating well, Translation of La scienza in cucina e l'arte di mangiar bene by Murtha Baca and Stephen Sartarelli. Toronto: University of Toronto Press, 2003.

Aston, G. Corpus use and learning to translate. Textus n. 12, 1999, pp. 289-314.

BAKER, M. Corpus linguistics and translation studies. Implications and applications. In: Baker, M.; Francis, G.; Tognini-Bonelli, E. (eds) Text and Technology. In Honour of John Sinclair. Amsterdam and Philadelphia: John Benjamins, 1993: 233-250.

BALLERINI, L. Introduction: A as in Artusi, G and Gentleman and Gastronome. In: ARTUSI, P. Science in the kitchen and the art of eating well, 2003, pp. xvi-lxxiv.

BALLERINI, L. Pellegrino Artusi in Nordamerica: Un caso di ostinazione. Paper presented at the Conference: Artusi, pellegrino nel mondo. Online: http://www.pellegrinoartusi.it/wpcontent/uploads/2011/02/Ballerinintervento.doc (visited: 24 August 2020), 2005.

BERNARDINI, S. Analisi di corpora per la traduzione: Una lezione introduttiva. Mediazioni, forthcoming.

BERNARDINI, S. and ZANETTIN, F. When is a universal not a universal? Some limits of current corpus-based methodologies for the investigation of translation universals, In: Mauranen, A. and Kujamäki, P. (eds). Translation universals. Do they exist? Amsterdam: John Benjamins, pp. 51-62, 2004.

Bernardini, S., P. Boulllon, D. Ciobanu, J. van Genabith, S. Hansen-Schirra, S. O'Brien, E. Steiner, E. TEICH, Language service provision in the 21st century: challenges, opportunities and educational perspectives for translation studies. In: Noorda, S., Scott, P. and Vukasovic, M. (eds), Bologna Process Beyond 2020, Bologna: Bononia University Press, 2020, pp. 297-303.

BLUM-KULKA, S., Shifts of cohesion and coherence in translation. In: House, J. and Blum-Kulka, S. (eds), Interlingual and intercultural communication. Tubingen: Gunter Narr Verlag, pp. 17-35. 
CAPATtI, A. Pellegrino Artusi. Il fantasma della cucina italiana. Milano: Mondadori Electa, 2019.

CAPATt, A. and Montanari, M. La cucina italiana. Storia di una cultura. Bari: Laterza, 2009.

EhLERS, U.-D. Future Skills for a European Higher Education. In: NooRdA, S., ScotT, P.; Vukasovic, M. (eds), Bologna Process Beyond 2020, Bologna: Bononia University Press, pp. 311-324, 2020.

EVERT, S. Corpora and collocations. In: LÜDELING, A.; KYTÖ, M. (eds), Corpus Linguistics. An International Handbook. Berlin: Mouton de Gruyter, pp. 1212-1248, 2009.

GAVIOLI, L. The learner as researcher. introducing corpus concordancing in the classroom. In: Aston, G. (ed) Learning with corpora. Bologna: CLUEB, 2001.

Gerhardt, Cornelia, Frobenius, M.; Ley, S. (eds) Culinary Linguistics: The Chef's Special. Amsterdam: John Benjamins, 2013.

GUTT, E. A. Translation and relevance. Cognition and context. Oxford. Blackwell, 1991.

JOHANSSON, S. Seeing through multilingual corpora. Amsterdam: John Benjamins, 2007.

JoHns, T. Should you be persuaded - Two samples of data-driven learning materials. In: JoHns, T.; KING, P. (eds). Classroom Concordancing pp. 116, 1991.

JURAFSKY, D. The Language of Food: A Linguist Reads the Menu. New York: W. W. Norton \& Company, 2014.

LAVIOSA, S. Core patterns of lexical use in a comparable corpus of English narrative prose. Meta, vol. 43 n. 4, pp. 557-570, 1998.

LANSTYÁk, I.; HeltAl, P. Universals in language contact and translation. Across Languages and Cultures vol. 13 n. 1, 99-121.

MalvaldI, M. Il borghese Pellegrino. Palermo: Sellerio, 2020.

MARCO, J. Translating style and styles of translating: Henry James and Edgar Allan Poe in Catalan, Language and Literature, vol. 13 n. 1, pp. 73-90.

NoRD, C. Text analysis in translation. Amsterdam: Rodopi, 1991.

Olohan, M. Scientific and technical translation. In: MILLÁN, C.; BARTRINA, F. (eds) The Routledge handbook of translation studies, London: Routledge, pp. 425-437, 2012.

PARADOWSKI, M. B. What's cooking in English culinary texts? Insights from genre corpora for cookbook and menu writers and translators. The Translator vol. 24, n. 1: 50-69, 2018.

REBECHI, R.; TAGNIN, S. Brazilian cultural markers in translation: A model for a corpus-based glossary, Research in Corpus Linguistics vol. 8, 65-85, 2020.

DE SAUSSURE, F. Cours de Linguistique Générale (edited by Charles Bally and Albert Sechehaye). Paris: Payot, 1916 [1971].

SCICOLONE, M. Foreword. In: ARTUSI, P. Science in the kitchen and the art of eating well, 2003, pp. x-xiii.

TradTerm, São Paulo, v.37, n. 2, janeiro/2021, p. 370-396

Número Especial - Linguística de Corpus

www. revistas.usp.br/tradterm 
SINCLAIR, H. MCH.; CARTER, R. Trust the text. Language, corpus and discourse, London: Routledge, 2004.

TAGNIN, S. Corpora and the innocent translator. Intralinea Special Issue (CULT2K), 2002.

TEICH, E. Crosslinguistic variation in system and text. Berlin: Mouton de Gruyter, 2003.

TOURY, G. Descriptive translation studies and beyond. Amsterdam: Benjamins, 2005.

WITTMAN, E. O. Literary narrative prose and translation studies. In: MILLÁN, C.; BARTRINA, F. (eds) The Routledge handbook of translation studies, London: Routledge, pp. 438-450, 2012.

XIAO, R.; HU, X. Corpus-Based Studies of Translational Chinese in EnglishChinese Translation, Berlin and Heidelberg: Springer Verlag, 2015.

Recebido em: 16/09/2020

Aceito em: 12/11/2020

Publicado em janeiro de 2021 